\title{
The Reform of Multimedia Teaching in Veterinary Medicine Course
}

\author{
Rongquan $\mathrm{Li}$
}

\author{
College of Animal Science and technology, Jilin Agricultural Science and Technology University
}

\author{
Keywords: Teaching Method; Classroom Teaching; Veterinary Medicine; Multimedia
}

\begin{abstract}
In order to probe into the teaching reform method of veterinary science course, the paper also studies the application techniques and common problems of multimedia teaching in the new educational idea, the author studies and expounds the teaching methods and teaching techniques in the classroom Teaching of veterinary medicine in combination with the experience of multimedia classroom teaching of veterinary medicine and the reform of university transformation. Some reference to the teaching reform of veterinary science course.

Under the new educational idea, the main objective of veterinary teaching is to cultivate student's practical ability and innovative pioneering ability. To enable students to learn skills as soon as possible, smooth and business, industry related business positions, reduce professional learning and business, the running-in period between the industry, to achieve professional skills seamless to the enterprise, Occupation or post of the profession ${ }^{[1]}$. Based on this, it is required that teachers should not only emphasize the cultivation and training of students ' practical ability in the course of veterinary medicine, but also strengthen the reform in the teaching of veterinary medicine, so that the reform of the teaching of veterinary medicine is the main position and key point of the teaching reform of the whole skill-oriented undergraduate course.

At present, in the teaching of veterinary medicine, multimedia teaching has become a necessary means of classroom teaching, what plays a very important role in the whole teaching, the teaching technique and teaching method of classroom teaching, even the teaching goal and teaching design, what are very important for the cultivation of the skill innovation pioneering talents ${ }^{[2]}$. Multimedia classroom teaching is the inevitable trend and necessary means of teaching modernization, changed the traditional way of relying solely on language and words to carry out classroom teaching, not only increased the amount of information in the classroom teaching, but also made the teaching of the problem of visualization, visualization, especially the use of the Internet, greatly facilitated and enriched the means and methods, so that the classroom is not only limited to three feet ${ }^{[3]}$. Based on the experience of multi-media teaching of veterinary medicine and the reform of teaching in college, the author studies and expounds the teaching methods and skills in the teaching of veterinary science to readers
\end{abstract}

\section{The Advantages of Multimedia Should be Played in Classroom Teaching Reform}

Increase the Amount of Information in the Classroom Teaching Content, Improve Iearning Efficiency. Compared with the traditional classroom teaching, multimedia teaching reduces the time of calligraphy and painting, the classroom information is greatly increased, the classroom becomes rich and compact ${ }^{[4]}$. Therefore, teachers ' work sharing is more beneficial to teachers to carry out more teaching work and improve work efficiency. meanwhile, the update speed of knowledge and information is also accelerated, which enriches the content of classroom teaching greatly. But it should pay attention to distinguish different student's quality condition and the different teaching goal request, cannot arbitrarily adjust, increases the student burden.

The Teaching Content Image, Vivid, Direct-viewing, Enhances the Student Attention Degree. The use of computers and the Internet has made it easier for teachers to prepare lessons ${ }^{[5]}$. So the teacher prepares lessons more fully, more convenient, classroom teaching content rich and colorful, pictures, videos, network resources more image, more intuitive, more conducive to teachers for the key, difficult to explain the problem, students are more easily memory and understanding, but also reduce the blackboard writing, painting time and graphics and text of the vivid. 
Create Independent Learning Conditions for Students, Improve Students ' Initiative Learning and Innovation Ability. Veterinary medicine requires students to have a strong practical ability and innovative ability, especially in the new education concept, autonomous learning and practical ability training is particularly important, and the application of multimedia teaching, increase the students ' active participation in the classroom teaching part, students can make full use of computers and the Internet to express their own problems, show their ability, At the same time, the students ' practical ability and innovative ability can be exercised, which provides a greater opportunity for the teaching of veterinary science. In addition, students actively use the computer and the Internet to participate in classroom teaching, but also improve the ability of students to use the computer and the Internet.

Make Full Use of Computer Skills and Methods, Enrich the Classroom Teaching Content, Active Classroom Teaching Atmosphere. At present, most of the classroom teaching of veterinary medicine has adopted PBL teaching, project-type, discussion-type, flip-type and other interactive teaching forms, and the use of multi-media teaching, more convenient and enrich the classroom teaching skills and teaching methods, active classroom atmosphere, changed the traditional teaching "rote", "You Say I remember" and other mechanical learning atmosphere, increased the interest of students to learn.

\section{The Disadvantage of Multimedia Should be Avoided in Classroom Teaching}

Too Much Emphasis on Computer Dkills and Methods, Ignoring or Masking the Teacher's Leading Role in the Classroom. Whether using a blackboard, or using a computer, whether it is taught from a podium, video, Micro-class, Mu-class, teacher's leading role is irreplaceable, each excellent teacher should have their own teaching skills, teaching results, teaching practices, production practices, these results can not be replaced by computer; In addition, the teacher's expression, movement, the thought, the sentiment as well as to the teaching scene at any time control, also cannot use the computer to replace. In particular, the teaching of veterinary specialized courses, young teachers often pass the skillful application of computer methods and techniques, ignoring the teacher's personal charm and will, practical ability, emphasizing the application of computer in the classroom, ignoring or concealing the real function and significance of the professional teacher's "classroom explanation". Therefore, teachers should not pay too much attention to the computer screen, but ignore the in-depth knowledge of the cases brought to students, and even teachers in the production of PPT, video, micro-class, too attached importance to visual effects or auxiliary effects, but neglected the teaching objectives, teaching content itself.

Form Too Single Board, Ignoring or Concealing the Teacher's Own Classroom Teaching Ability. Regardless of the traditional teaching method, or the present multi-media auxiliary teaching, the teacher's leading role cannot be changed, if the teacher own quality or the ability lacks, the multimedia classroom teaching also will appear the form which is inflexible, the content is rigid, the means single and other traditional blackboard teaching problems ${ }^{[6]}$. Therefore, no matter which kind of teaching form, the teacher's own ability to control the classroom is vital, especially to the classroom at any time of the temporary regulation of the situation, which is the multi-media teaching should be paid special attention.

Ignoring or Concealing the Ability of the Teacher's Production Practice According to the Teaching of "Screen". In order to avoid the problem that the students do not pay attention to the teaching in class, the teacher should attach importance to the close collective production practice. Whether it is according to the books, or the teaching of "screen", the fundamental reason is that the teacher's own production practice ability is weak. This is the case for individual teachers, whether they are young teachers who have just joined the work, or if they are old teachers who have been out of production practice for a long time. Multimedia teaching, like traditional blackboard teaching method, is an assistant means of teacher's classroom teaching, and multimedia classroom teaching, because of its convenience, can easily ignore or conceal the deficiency or limitation of teachers ' ability in production practice, and make teachers more detached from production reality [7]. Therefore, the teacher actively participates in the production practice exercise, can make the 
classroom teaching more colorful, the real, the student can feel the curriculum to be more valuable, more meaningful.

\section{Problems to be Paid Attention to When Choosing Teaching Materials}

The Requirements of PPT Production in Classroom Teaching. PPT, the meaning of "briefing", is a software developed to facilitate the display of major issues and key links as well as graphics and video information to the audience. It requires content to be vivid, concise, illustrated, audio-visual coexistence, and not just to reduce writing time, or ignore the leading role of explanation.

The use of PPT teaching should pay attention to the classroom content of the system, orderly, to facilitate memory, to highlight the key content, so that students have to be found, difficult problems in a variety of ways to explain, easy to understand memory; font and background should be a considerable degree of chromatic aberration, to facilitate students to watch; the size of the PPT should not be too small, I think no less than 28th, must not be able to copy the textbook text completely to the PPT; PPT layout should be concise, the number of words should not be too much, to avoid the students have been bowed down records of the situation; Choose concise, popular fonts, easy to identify and memory; PPT layout should not be too "fancy" or insert some pictures, animations that are irrelevant to the teaching content. distraction of students ' energy; animation, action buttons, hyperlinks and so on, which not too much, not easy too cumbersome, affect the efficiency of the class, distract students attention.

Typical, Accurate and Accurate of the Data in Picture and Video. The pictures in multimedia teaching are usually used in PPT and video, streaming media, in the picture selection, because of the limitations of the picture selection, in the definition, typical, accuracy and many other aspects of the unsatisfactory, to explain the problem can not give an accurate or typical auxiliary role, sometimes even one-sided, Wrong pictures and video materials, teachers and students have negative effects, or " be wide of the mark ", " deliberately misrepresent " and other far-fetched graphics and text, audio-visual materials. Therefore, in the production of PPT and video, should pay attention to the selected pictures, video on the classroom in the lecture on whether the problem is specific, whether it is typical, accurate and correct.

Rational use of computer and Internet technology. The use of computer and Internet has greatly promoted the reform and progress of classroom teaching, not only improved the working efficiency, but also greatly improved the effect of classroom teaching [8], therefore, no matter veterinary science course, or other specialized course teaching, multimedia classroom teaching is the general trend. But it should be noted that the computer and the Internet also have a variety of factors affecting the teaching of interference, bad factors, and there are many pseudoscience, regardless of teacher preparation, or students self-learning, which need distinction and attention.

The function of "highlighting" in micro-lesson and Mu-class. Mu class is a professional course using multimedia and the Internet for teaching, image, vivid, without losing interest; micro-class is a part of the course, made video or multimedia, using the Internet for teaching, compared with MU class more applicable, more flexible ${ }^{[9]}$. Micro-course and $\mathrm{Mu}$-Cai are popular multimedia teaching methods at present. However, it should be noted that the teaching content requirements of the micro-curriculum should conform to or follow the teaching objectives and requirements of the course, and should not be divorced from the original teaching objectives and teaching requirements because of the need of video production or in order to increase the sensory effect. The main content of the course or key content, can not appear "once and for all" completely deviated from the classroom teaching requirements

The leading role of teachers and the auxiliary function of multimedia in the classroom teaching of veterinary medicine should complement each other. The teaching of veterinary medicine in class is more in line with the "master-apprentice" approach, no matter the use of any teaching methods, teaching skills, can not forget the teacher or "master" experience and the teaching and learning, to bear in mind the classroom teaching, the teacher for the director (Leading role), students as the protagonist (main position) of the important forms of instruction, any teaching 
methods, Teaching skills are the auxiliary of teachers ' learning, not the whole of classroom teaching

The teacher's own comprehensive quality and business ability are always the important basis of classroom teaching effect. The effect of multimedia classroom teaching is good or bad, not only depends on the level of computer use of teachers, multimedia production skills, more importantly, the teachers themselves constantly improve the comprehensive quality and professional skills, professional knowledge and other business capabilities, that is, "iron also need their own hard", multimedia is only a substitute for blackboard classroom teaching auxiliary form.

\section{Conclusion}

Veterinary Medicine Classroom teaching, in the whole student university study occupies a large proportion, what is the main way for students to learn knowledge, regardless of the traditional blackboard teaching, or the present multi-media teaching, should pay attention to the students ' main position, the teacher's active role, at the same time, not to multimedia for all teaching tasks, teachers own professional knowledge and skill are the most important.

\section{Acknowledgements}

Jilin Province Education Science "Thirteen-Five" Key Planning Project Fund (ZD16049)

\section{References}

[1] Long Junling. Discussion on using multimedia to carry out effective classroom teaching [J]. Journal of Puer University , 2015,31 (2): 138-140

[2] Tan Yuanyuan and so on. A comparative study of traditional classroom teaching and multimedia teaching $[\mathrm{J}]$. Journal of Guangxi Teachers Education University: Natural Science Edition, 2016,33 (2): 120-123

[3] Ji Kaiyu. The application of multimedia audiovisual technology in the classroom [J]. Vocational Technology 2015,14 (12): 38-40

[4] Yin Jingqi. Multimedia Technology 2nd edition [M]. Beijing: Machinery Industry Press, 2010

[5] Shi Yuying. On the application of multimedia technology in teaching--also on the advantages and disadvantages of multimedia teaching [J]. Computer CD Software and Applications, 2012, (16): 33-35

[6] Wang Lumei. The application of multimedia in the classroom teaching of university [J]. The Guide of Science \& Education, 2012, (20): 138-140

[7] Rong Mansheng. Thinking and exploring of multimedia teaching in colleges and universities [J]. E-education Research, 2009, (03): 44-45

[8] Liu Hehai, Wang Qing. Investigation and research on the present situation of multimedia teaching in colleges and universities [J]. Education and Modernization, 2006, (02): 66-68

[9] Rong Mansheng.On modern education technology training of university teachers [J]. Education Informatization, 2012, (12): 22-24 